\title{
Exogenous Glycinebetaine Promotes Soil Cadmium Uptake by Edible Amaranth Grown during Subtropical Hot Season
}

\author{
Wei-Qing Yao ${ }^{1}$, Yong-Kang Lei ${ }^{2}$, Ping Yang ${ }^{2}{ }^{\circledR}$, Qu-Sheng $\mathrm{Li}^{2, *}$, Li-Li Wang ${ }^{2}$, Bao-Yan He ${ }^{2}$, \\ Zhi-Min $\mathrm{Xu}^{2}$, Chu Zhou ${ }^{2}$ and Han-Jie $\mathrm{Ye}^{2}$ \\ 1 Guangdong Polytechnic of Environmental Protection Engineering, Foshan 528216, China; yaofast1@163.com \\ 2 School of Environment, Key Laboratory of Environmental Pollution and Health of Guangdong Province, \\ Jinan University, Guangzhou 511443, China; leiyongkang0611@163.com (Y.-K.L.); yangp35@jnu.edu.cn (P.Y.); \\ wanglili@jnu.edu.cn (L.-L.W.); thbyan@jnu.edu.cn (B.-Y.H.); cloris59420@163.com (Z.-M.X.); \\ zhouchuzhc@163.com (C.Z.); a3192396@163.com (H.-J.Y.) \\ * Correspondence: liqusheng@21cn.com; Tel.: +86-20-8522-7987; Fax: +86-20-8522-6615
}

Received: 20 July 2018; Accepted: 6 August 2018; Published: 21 August 2018

\begin{abstract}
Exogenous glycinebetaine treatment is an effective measure for preventing crops from being exposed to drought and high temperature; however, the effects of this approach on the soil $\mathrm{Cd}$ uptake and accumulation by crops remain unclear. Pot experiments were conducted in this study to analyze the effect of glycinebetaine on the soil $\mathrm{Cd}$ uptake and accumulation by edible amaranth cultivated in Cd-contaminated soil. Results revealed that after exogenous glycinebetaine treatment on amaranth leaves during the vigorous growth period, the plant biomass, the $\mathrm{Cd}$ concentrations in the roots and shoots, and the $\mathrm{Cd}$ translocation factor (TF) were significantly higher than those of the control group. The highest $\mathrm{Cd}$ concentrations in the roots and shoots and the TF were higher by $91 \%, 96 \%$ and $23.8 \%$, respectively, than the corresponding values in the control group. In addition, exogenous glycinebetaine treatment significantly increased leaf chlorophyll content and promoted the photosynthesis of edible amaranth. Consequently, the contents of soluble sugar, dissolved organic carbon, and low-molecular-weight organic acids significantly increased in the rhizosphere, resulting in $\mathrm{Cd}$ mobilization. Significant positive correlations were observed among the contents of leaf chlorophyll, $\mathrm{Mg}$, $\mathrm{Fe}$, pectin and $\mathrm{Ca}$. Given that $\mathrm{Cd}$ shares absorption and translocation channels with these elements, we speculated that the increased leaf chlorophyll and pectin contents promoted the absorption and accumulation of $\mathrm{Mg}$, $\mathrm{Fe}$ and $\mathrm{Ca}$, which further promoted the absorption and translocation of $\mathrm{Cd}$. These results indicated that exogenous glycinebetaine treatment during hot season would aggravate the health risks of crops grown in Cd-contaminated soils.
\end{abstract}

Keywords: lycine; high temperature; Cd; Amaranthus; chlorophyll; pectin

\section{Introduction}

Glycinebetaine (GB) is one of the main organic osmoregulators of plants. Plants can be exposed to various stresses, such as salt, drought, or high temperature, and glycinebetaine can exert osmoregulation synergistically with proline and soluble sugars to enhance plant resistance $[1,2]$. Glycinebetaine enhances the resistance of plants to salt [3-5], drought [6,7], and cold stress [8].

Exogenous glycinebetaine can also effectively mitigate high-temperature stress in crops [9-11]. Previous studies found that exogenous glycinebetaine alleviates the decline in photosynthetic rate due to stomatal limitation and attenuates the effect of high temperature on the photosynthetic physiological processes of plants [12,13]. Kanechi et al. [9] reported that glycinebetaine could significantly increase 
the chlorophyll content in tomato plants under high-temperature stress and enhance photosynthesis. Glycinebetaine could improve the high-temperature resistance of transgenic wheat by protecting the repair cycle of photosystem II [14]. In addition, exogenous glycinebetaine treatment promotes high-temperature resistance and growth in transgenic codA genes (a gene encodes choline oxidase, the enzyme that converts choline to glycinebetaine) of Arabidopsis [15] and transgenic BADH genes (a gene encoding betaine aldehyde dehydrogenase) of wheat [16]. Therefore, exogenous glycinebetaine is introduced in some regions to resist high temperatures and promote crop growth. In recent years, many soils have been contaminated by heavy metals, such as $\mathrm{Cd}$, due to human activities (such as smelt, long-term application of chemical fertilizer, sewage irrigation). Cd can easily enter the food chain through crop enrichment, posing a health risk to humans $[17,18]$. Although glycinebetaine treatment can protect crops against drought and high-temperature stress, its effects on the soil $\mathrm{Cd}$ uptake and accumulation by crops remain unclear. Previous studies reported that exogenous glycinebetaine treatment could significantly inhibit the Cd uptake by tobacco cells [19] and increase the $\mathrm{Cd}$ concentration in maize seeds [20]. Exogenous glycinebetaine treatment could significantly alleviate the Cd stress of mung bean seedlings [21], rice seedlings [22], and cotton seedlings [23] by enhancing the activity of antioxidant enzymes. However, these studies failed to clarify the mechanism by which glycinebetaine affects the soil $\mathrm{Cd}$ uptake and accumulation by crops.

The Cd concentration in agricultural soils in the Pearl River Delta area far exceeds the standard of "Farmland environmental quality evaluation standards for edible agricultural products (HJ 332-2006, China)" (Cd $\leq 0.3 \mathrm{mg} \mathrm{kg}^{-1}$, in soil with $\left.\mathrm{pH} \leq 7.5\right)$, such that planting crops in this subtropical region presents environmental risks [24,25]. Moreover, the increased transpiration during the hot season relative to that during cool season would intensify the soil Cd uptake and accumulation by crops, thereby aggravating the environmental risks [26]. Therefore, this paper assumed that exogenous glycinebetaine treatment on leaves may affect the soil $\mathrm{Cd}$ uptake and accumulation by vegetables in the subtropical hot season. To verify this hypothesis, experiments were conducted using edible amaranth, which is widely grown in the subtropical hot season and has a high edible value. The specific objectives were as follows: (1) to determine the Cd concentrations in the rhizosphere soil solution, the roots, and the shoots after exogenous glycinebetaine treatment of different concentrations on the leaves at different growth stages of edible amaranth; (2) to analyze the changes in the soluble sugar, dissolved organic carbon (DOC), and low-molecular-weight organic acids (LMWOAs) in the rhizosphere soil solution of amaranth after exogenous glycinebetaine treatment, as well as their relationship to the $\mathrm{Cd}$ mobilization in the rhizosphere soil; and (3) to investigate the changes in pectin, chlorophyll, $\mathrm{Ca}, \mathrm{Mg}$, and Fe contents, as well as their relationship to the $\mathrm{Cd}$ uptake and accumulation by edible amaranth after exogenous glycinebetaine treatment.

\section{Materials and Methods}

\subsection{Experimental Crops and Soil}

Liuye edible amaranth (Amaranthus mangostanus L.) was selected as the study object, and the seeds were purchased in the local market of Guangzhou, China. Glycinebetaine anhydrous was acquired from Sigma. The potting soil for the experiment was collected from the vegetable garden soil in the suburbs of Guangzhou City, Guangdong Province. The soil was irrigated with sewage 20 years ago. The experimental soil had a $\mathrm{pH}$ of 6.35 , a total organic carbon of $35.4 \mathrm{~g} \mathrm{~kg}^{-1}$, a cation exchange capacity of $20.86 \mathrm{cmol} \mathrm{kg}^{-1}$, and a Cd concentration of $1.81 \pm 0.10 \mathrm{mg} \mathrm{kg}^{-1}$, which was significantly higher than the standard $\mathrm{Cd}$ concentration of $0.3 \mathrm{mg} \mathrm{kg}^{-1}$ in the "Farmland environmental quality evaluation standards for edible agricultural products" (HJ 332-2006). Therefore, the experimental soil was a Cd-contaminated soil. The soils of the tillage layer $(0-15 \mathrm{~cm})$ were collected and transported to a glasshouse for natural drying. After the moisture content was determined, the soil was ground and sieved $(2 \mathrm{~mm})$ and thoroughly mixed for the pot experiments. 
The pot experiments were performed in a glasshouse located on the campus of Jinan University $\left(120^{\circ} 58^{\prime} \mathrm{E}, 23^{\circ} 58^{\prime} \mathrm{N}\right)$. Accurately weighed $2.20 \mathrm{~kg}$ soil samples were placed in plastic pots (pot height: $15 \mathrm{~cm}$; pot base diameter: $15 \mathrm{~cm}$ ). The experimental amaranth seeds were soaked in disinfectant solution $(0.05 \%$ carbendazim) for $25 \mathrm{~min}$ and then rinsed with tap water and deionized water. Then, the seeds were sown in nylon mesh in the plastic pots. Plastic trays were placed under the pots. The water content was maintained at about $75 \%$ of the field moisture capacity, and the percolation water produced by irrigation was recharged to the soil. During the experiment, the temperature in the greenhouse during daytime was maintained at $36-42{ }^{\circ} \mathrm{C}$ for $6 \mathrm{~h}$ (from 10 a.m. to 4 p.m.).

The experimental design consisted of two series. For Series 1, potted amaranth leaves were subjected to exogenous glycinebetaine treatment at five levels $\left(1,5,10,20\right.$ and $\left.50 \mathrm{mmol} \mathrm{L}^{-1}\right)$ at different growth stages (early growth, Day 18; vigorous growth, Day 30). Glycinebetaine was applied on the leaves once every 2 days for three times, and deionized water was used as the blank control (glycinebetaine: $0 \mathrm{mmol} \mathrm{L}^{-1}$ ). Each treatment was repeated five times, and the total number of pots was 60 . This series was established to investigate the soil $\mathrm{Cd}$ uptake and accumulation by amaranth after foliar exogenous glycinebetaine treatment of different concentrations at different growth stages. For Series 2, according to the results of Series 1, exogenous glycinebetaine treatment was applied on the amaranth leaves at the vigorous growth stage at three levels $\left(5,10\right.$ and $\left.50 \mathrm{mmol} \mathrm{L}^{-1}\right)$ and a blank control $\left(0 \mathrm{mmol} \mathrm{L}^{-1}\right)$. The other experimental conditions were the same as those of Series 1 , and the total number of pots was 20. The purpose of this series was to examine the changes in the rhizosphere soluble sugar, DOC, LMWOAs, and in the leaf chlorophyll and pectin. The amaranth in both experiment series was grown for 50 days and then harvested at 6:00 AM.

\subsection{Sample Determination}

After the plants in Series 1 were washed clean and dried with filter paper, their fresh weight was measured. The plants were placed in an oven and de-enzymed at $105^{\circ} \mathrm{C}$ for $15-20 \mathrm{~min}$. Then, the temperature was maintained at $70-80^{\circ} \mathrm{C}$ until a constant weight was achieved, and the dry weight was measured. The plants were pulverized with a plant grinder. Accurately weighed $0.3 \mathrm{~g}$ powder samples were digested with $\mathrm{HNO}_{3}$ in a microwave digestion instrument. The digested solution was adjusted to $25 \mathrm{~mL}$ with deionized water and was used to determine the $\mathrm{Cd}$ concentrations in the roots and the shoots.

After the plants in Series 2 were washed clean and dried with filter paper, their fresh weight was measured. A selected part of the root, stem, and leaf was quick-frozen in liquid nitrogen and then stored at $0-4{ }^{\circ} \mathrm{C}$ to measure the soluble sugar and pectin contents. The soluble sugar content of root was determined using anthrone colorimetry [27], and the total pectin content of leaf was obtained using galacturonic acid colorimetry [28]. The remaining samples were dried, and a part leaf was used to determine the chlorophyll content. Chlorophyll was extracted by using 95\% ethanol, and its content was determined by UV mini-1240 UV-Vis spectrophotometer (Shimadzu, Kyoto, Japan) [29]. Parts of the dried samples were ground and digested to determine the concentration of $\mathrm{Cd}, \mathrm{Ca}, \mathrm{Mg}$, and $\mathrm{Fe}$ in the root, stem, and leaf. At the same time as the plants were harvested, the rhizosphere soil in the nylon mesh was placed in sealed bags. The rhizosphere soil solution was collected using the high-speed centrifugation method [30]. The soil solution was filtered twice with a $0.45-\mu \mathrm{m}$ filter, and then stored in a $-80{ }^{\circ} \mathrm{C}$ freezer for determination of the contents of $\mathrm{Cd}$, soluble sugar, DOC, and LMWOAs [31].

The $\mathrm{Cd}$ concentration was measured by graphite furnace atomic absorption spectrophotometry (GF-AAS-7000A, Shimadzu, Kyoto, Japan), and the Ca, Mg, and Fe contents were determined by inductively coupled plasma optical emission spectrometry (ICP-OES Avio200, PerkinElmer, Waltham, MA, USA). The plant standard sample (GSV-1 national standard reference material) was used for quality control, and the recovery rate was $85-110 \%$. The DOC content was measured using a dissolved organic carbon analyzer (Toc-Vcsh, Shimadzu, Kyoto, Japan). LMWOAs were measured by gradient elution ion chromatography (ICS-1100, DIONEX, Sunnyvale, CA, USA). 


\subsection{Data Analysis}

The translocation factor (TF) was calculated using Equation (1):

$$
\mathrm{TF}_{\mathrm{Cd}}=\mathrm{Cd}_{\text {shoot }} / \mathrm{Cd}_{\text {root }}
$$

$\mathrm{Cd}_{\text {root }}$ (fresh weight, $\mu \mathrm{g} \mathrm{g}^{-1}$ ) and $\mathrm{Cd}_{\text {shoot }}$ (fresh weight, $\mu \mathrm{g} \mathrm{g}^{-1}$ ) represent the $\mathrm{Cd}$ concentration in the amaranth roots and shoots, respectively.

The total $\mathrm{Cd}$ amount accumulated in plant $\left(\mathrm{Cd}_{\mathrm{accu}}\right.$ (fresh weight, $\mu \mathrm{g}$ pot $\left.\left.^{-1}\right)\right)$ was calculated using Equation (2):

$$
\mathrm{Cd}_{\mathrm{accu}}=\mathrm{Cd}_{\text {root }} \times \mathrm{W}_{\text {root }}+\mathrm{Cd}_{\text {shoot }} \times \mathrm{W}_{\text {shoot }}
$$

$\mathrm{W}_{\text {root }}\left(\mathrm{g} \mathrm{pot}^{-1}\right)$ and $\mathrm{W}_{\text {shoot }}\left(\mathrm{g} \mathrm{pot}^{-1}\right)$ represent the weight of amaranth roots and shoots in each pot, respectively.

The total amount of mobilized $\mathrm{Cd}$ in the rhizosphere soil $\left(\mathrm{Cd}_{\text {total }}\left(\mu \mathrm{g} \mathrm{pot}{ }^{-1}\right)\right)$ was calculated using Equation (3):

$$
\mathrm{Cd}_{\text {total }}=\left(\mathrm{Cd}_{\text {accu }}+\mathrm{Cd}_{\text {rhizo }} \times \mathrm{W}_{\text {rhizo }}\right)
$$

$\mathrm{Cd}_{\text {rhizo }}$ ( $\mu \mathrm{g} \mathrm{g}^{-1}$ dry soil weight) represents the $\mathrm{Cd}$ concentration in the amaranth rhizosphere soil solution, and $\mathrm{W}_{\text {rhizo }}\left(\mathrm{g} \mathrm{pot}^{-1}\right)$ represents the dry weight of the rhizosphere soil in each pot.

Statistical analysis was conducted using SPSS 19.0 (IBM, Armonk, NY, USA). The kurtosis and skewness of each sample was in a reasonable range $(-1,1)$, and a Q-Q plot indicated that each point approximately surrounded a straight line, indicating that each sample was approximately normal distribution. Data were tested at significance levels of $p<0.05$ by student's $t$-test and ANOVA Duncan test. Origin 9.0 software (OriginLab, Northampton, MA, USA) was used to draw the graphs.

\section{Results and Discussion}

\subsection{Biomass and $\mathrm{Cd}$ Concentration in Edible Amaranth after Exogenous Glycinebetaine Treatment at Two Growth Stages}

Figure 1 shows the biomass, Cd concentration in the plant, and the Cd TF after exogenous glycinebetaine treatment on the leaves at two growth stages of amaranth. The results revealed that the biomass of most treated plants was significantly higher than that of the control (Figure 1a), indicating that glycinebetaine can alleviate high-temperature stress and promote plant growth. This finding was consistent with the results of Kanechi et al. [9]. As shown in Figure 1b, when exogenous glycinebetaine treatments of different concentrations were applied to the amaranth leaves of the same growth stage, the $\mathrm{Cd}$ concentrations in the roots and the shoots were significantly higher $(p<0.05)$ than those of the control, and the highest $\mathrm{Cd}$ concentrations in the roots and the shoots were higher by $91 \%$ and $96 \%$, respectively, than that in the control. The shoots of amaranth are the main edible parts. The $\mathrm{Cd}$ concentrations in the roots and the shoots of plants in the vigorous growth stage were significantly higher $(p<0.05)$ than those of the early growth stage. After exogenous glycinebetaine treatment on the leaves of plants in the early and vigorous growth stages, the average $\mathrm{Cd}$ concentrations in the shoots were 0.40 and $0.47 \mu \mathrm{g} \mathrm{g}^{-1}$, respectively, which were $33-57 \%$ higher than those in the control (Cd concentration: $0.3 \mu \mathrm{g} \mathrm{g}^{-1}$ ). This result implied that the exogenous glycinebetaine treatment on the leaves greatly intensified the human health risk of edible amaranth. The TF of $\mathrm{Cd}$ from the roots to the shoots significantly increased under 1 and $5 \mathrm{mM}$ treatments relative to that of the control, with the highest increase recorded at $33.2 \%$. However, the change was insignificant, and the TF even significantly decreased under a high-concentration treatment (Figure 1c). This finding showed that a low-concentration glycinebetaine treatment promoted the translocation of $\mathrm{Cd}$ from the roots to the shoots, whereas a high concentration inhibited the translocation. In view of the greater effect of glycinebetaine treatment on the $\mathrm{Cd}$ uptake and accumulation at the vigorous growth stages, the following experiments were conducted under glycinebetaine treatment on the leaves of amaranth during the vigorous growth stage. 


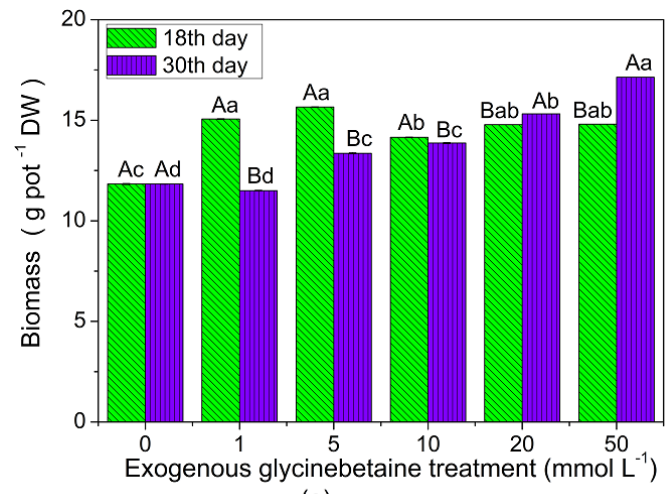

(a)

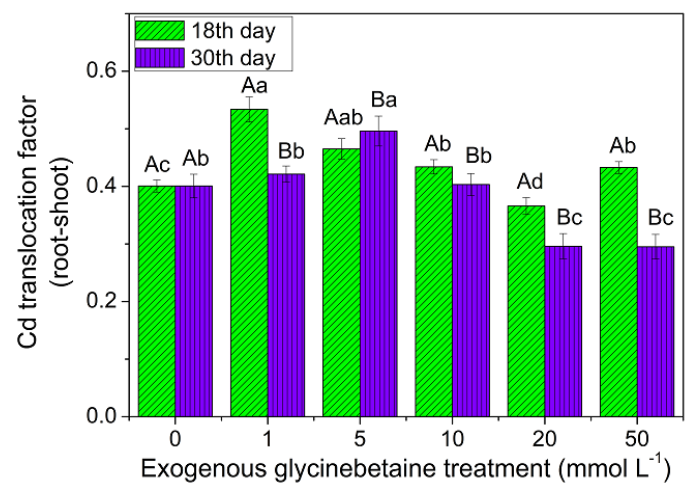

(c)

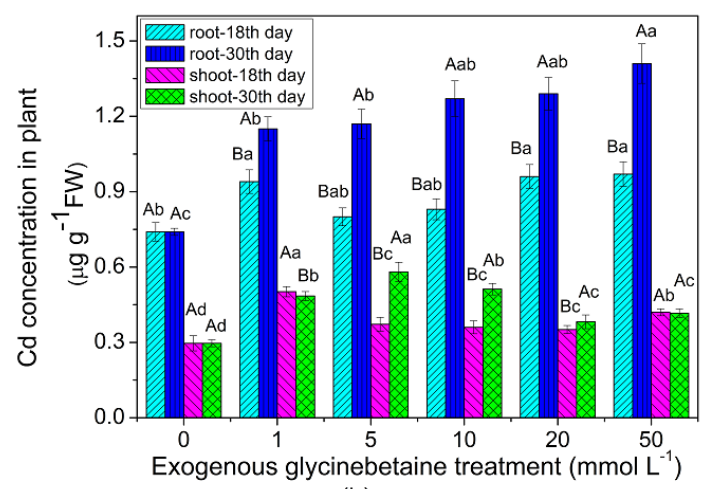

(b)

Figure 1. Biomass (a), Cd concentration in plant (b), and Cd translocation factor (c) under exogenous glycinebetaine treatment at two growth stages of edible amaranth.

The capital letters (A and B) indicate significant differences between two growth stages under the same treatment for root or shoot (student's $t$-test, $p<0.05)$. The lowercase letters $(a, b, c$ and $d)$ indicate significant differences between different treatments in the same growth stages (ANOVA Duncan test, $p<0.05)$. The number of each group sample was five $(n=5)$.

\subsection{Soluble Sugar Content in the Amaranth Roots, Contents of Soluble Sugar, DOC, and LMWOAs in the} Rhizosphere Solution and their Relationship with Cd Mobilization in Rhizosphere Soil

As shown in Figure 2, the soluble sugar content in the roots significantly increased $(p<0.05)$ after exogenous glycinebetaine treatment on the leaves. When the glycinebetaine concentration was $50 \mathrm{mM}$, the soluble sugar content in the roots was the highest, which was $62.52 \%$ higher than that of the control. Significant differences $(p<0.05)$ were observed in the effects of different concentrations of glycinebetaine treatments. Gao et al. [32] reported that exogenous glycinebetaine treatment increases the contents of proline and soluble sugar in tomato plants. High temperatures promote leaf transpiration and cause water loss, thereby closing the stomata and inhibiting photosynthesis. Exogenous glycinebetaine can quickly seep into plant organs, preserve the osmotic potential in the leaves, alleviate the stomatal limitation caused by high-temperature stress, and, therefore, enhance photosynthesis and increase the soluble sugar content in the roots [8]. 


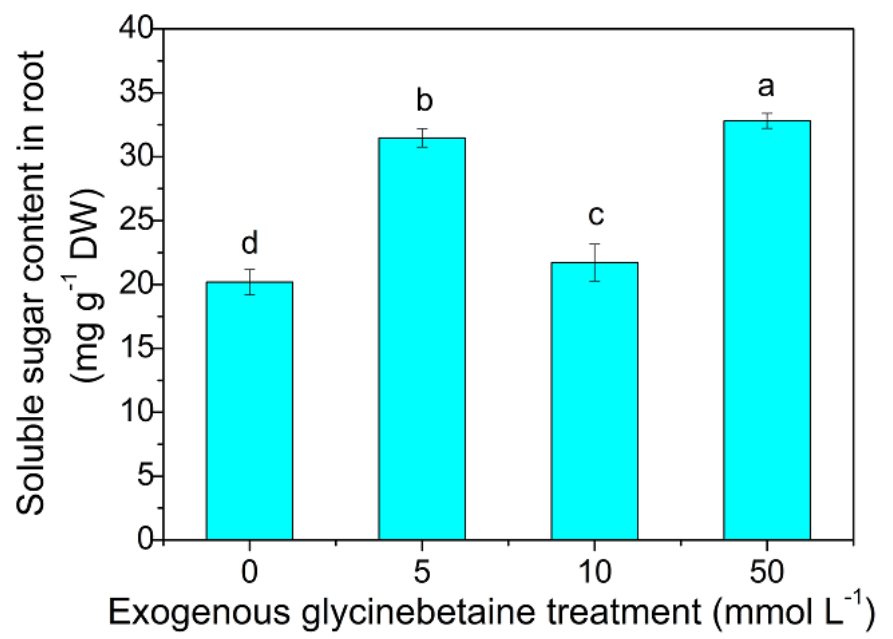

Figure 2. Soluble sugar content in the roots of control and exogenous glycinebetaine treatment plants. Different lowercase letters indicate significant difference between treatments (ANOVA Duncan test, $p<0.05)$. The number of each group sample was five $(n=5)$.

Table 1 shows the total mobilized $\mathrm{Cd}$ amount in the rhizosphere soils and the changes in the soluble sugar, DOC, and LMWOAs contents in the rhizosphere soil solution after exogenous glycinebetaine treatment. After exogenous glycinebetaine treatment, $\mathrm{Cd}_{\text {total }}$ significantly increased $(p<0.05)$, and the mean value was 1.66 times higher than that of the blank control. Table 1 also shows that glycinebetaine significantly increased the DOC, LMWOAs, and soluble sugar contents $(p<0.05)$ in the rhizosphere soil solution, and the corresponding mean values were 1.37, 3.73 and 2.36 times higher than that of the blank control, respectively. A significant positive correlation existed between $\mathrm{Cd}_{\text {total }}$ and DOC, LMWOAs, and soluble sugars at the 0.05 level (Table 2). LMWOAs are part of the DOC and not only directly chelate $\mathrm{Cd}$ to enhance soil $\mathrm{Cd}$ mobility but also acidify the rhizosphere soils to improve the bioavailability of heavy metals [33,34]. Therefore, LMWOAs play a key role in the metal mobilization in the rhizosphere soil. The literature confirmed that glucose metabolism produces more LMWOAs [30]. We speculate that exogenous glycinebetaine treatment promotes the photosynthesis of amaranth and increases the soluble sugar content of root, which further increases the total contents of DOC, LMWOAs, and soluble sugar in the rhizosphere soil. In addition, DOC, LMWOAs, and soluble sugars provide nutrients to the rhizosphere microorganisms, increasing their abundance. In turn, the rhizosphere microorganisms enhance the bioavailability of $\mathrm{Cd}$ by dissolving insoluble $\mathrm{Cd}$ through their metabolism.

Table 1. Total Cd mobilization in the rhizosphere soils and the soluble sugar, dissolved organic carbon (DOC), and low-molecular-weight organic acids (LMWOAs) contents in the rhizosphere soil solution after exogenous glycinebetaine treatment.

\begin{tabular}{ccccc}
\hline \multirow{2}{*}{$\mathbf{G B} / \mathbf{m M}$} & $\mathrm{Cd}_{\text {total }}\left(\mu \mathbf{g ~ p o t}^{-\mathbf{1})}\right.$ & \multicolumn{3}{c}{ Rhizosphere Soil Solution } \\
\cline { 3 - 5 } & & $\begin{array}{c}\text { DOC } \\
\left(\mu \mathbf{g}^{-\mathbf{1}} \mathbf{D W}\right)\end{array}$ & $\begin{array}{c}\text { LMWOAs } \\
\left(\mu \mathbf{g ~ g}^{-\mathbf{1}} \mathbf{D W}\right)\end{array}$ & $\begin{array}{c}\text { Soluble Sugar } \\
\left(\boldsymbol{\mu} \mathbf{~ k g}^{-\mathbf{1}} \mathbf{D W}\right)\end{array}$ \\
\hline 0 & $1.02 \pm 0.02 \mathrm{~d}$ & $64.5 \pm 1.01 \mathrm{~d}$ & $1.24 \pm 0.14 \mathrm{~d}$ & $6.14 \pm 0.21 \mathrm{~d}$ \\
5 & $1.63 \pm 0.01 \mathrm{c}$ & $82.0 \pm 1.23 \mathrm{c}$ & $3.65 \pm 0.11 \mathrm{c}$ & $12.0 \pm 0.10 \mathrm{c}$ \\
10 & $1.77 \pm 0.04 \mathrm{a}$ & $90.1 \pm 0.80 \mathrm{~b}$ & $5.75 \pm 0.29 \mathrm{a}$ & $15.3 \pm 0.45 \mathrm{~b}$ \\
50 & $1.69 \pm 0.02 \mathrm{~b}$ & $93.1 \pm 0.20 \mathrm{a}$ & $4.51 \pm 0.21 \mathrm{~b}$ & $16.2 \pm 0.19 \mathrm{a}$ \\
GB average & 1.70 & 88.4 & 4.64 & 14.5 \\
GB average/0 (fold) & 1.66 & 1.37 & 3.73 & 2.36 \\
\hline
\end{tabular}

GB: glycinebetaine. Different lowercase letters indicate significant difference in the column (ANOVA Duncan test, $p<0.05)$. The number of each group sample was five $(n=5)$. Values are presented as means $\pm \mathrm{SD}$. 
Table 2. Correlations between total $\mathrm{Cd}$ mobilization $\left(\mathrm{Cd}_{\text {total }}\right)$ in the rhizosphere soil and the soluble sugar, DOC, and LMWOAs contents in the rhizosphere solution.

\begin{tabular}{cccc}
\hline Statistical Indicators & DOC & LMWOAs & Soluble Sugar \\
\hline $\mathrm{R}^{2}$-value & 0.874 & 0.867 & 0.855 \\
$p$-value & $0.043<0.05$ & $0.045<0.05$ & $0.049<0.05$ \\
\hline \multicolumn{4}{c}{ The number of each group sample was five $(n=5)}$.
\end{tabular}

As shown in Figure 3, after exogenous glycinebetaine treatment, $\mathrm{Cd}_{\text {rhizo }}$ presented a significant positive correlation with $\mathrm{Cd}_{\text {root }}$ and $\mathrm{Cd}_{\text {shoot }}$ in amaranth $\left(\mathrm{R}^{2}=0.5280,0.7156 ; p<0.01,0.01\right)$, indicating hat $\mathrm{Cd}$ mobilization in the rhizosphere soil played an important role in the $\mathrm{Cd}$ accumulation in the roots and the shoots of edible amaranth. This finding was consistent with the result of Xu et al. [35].

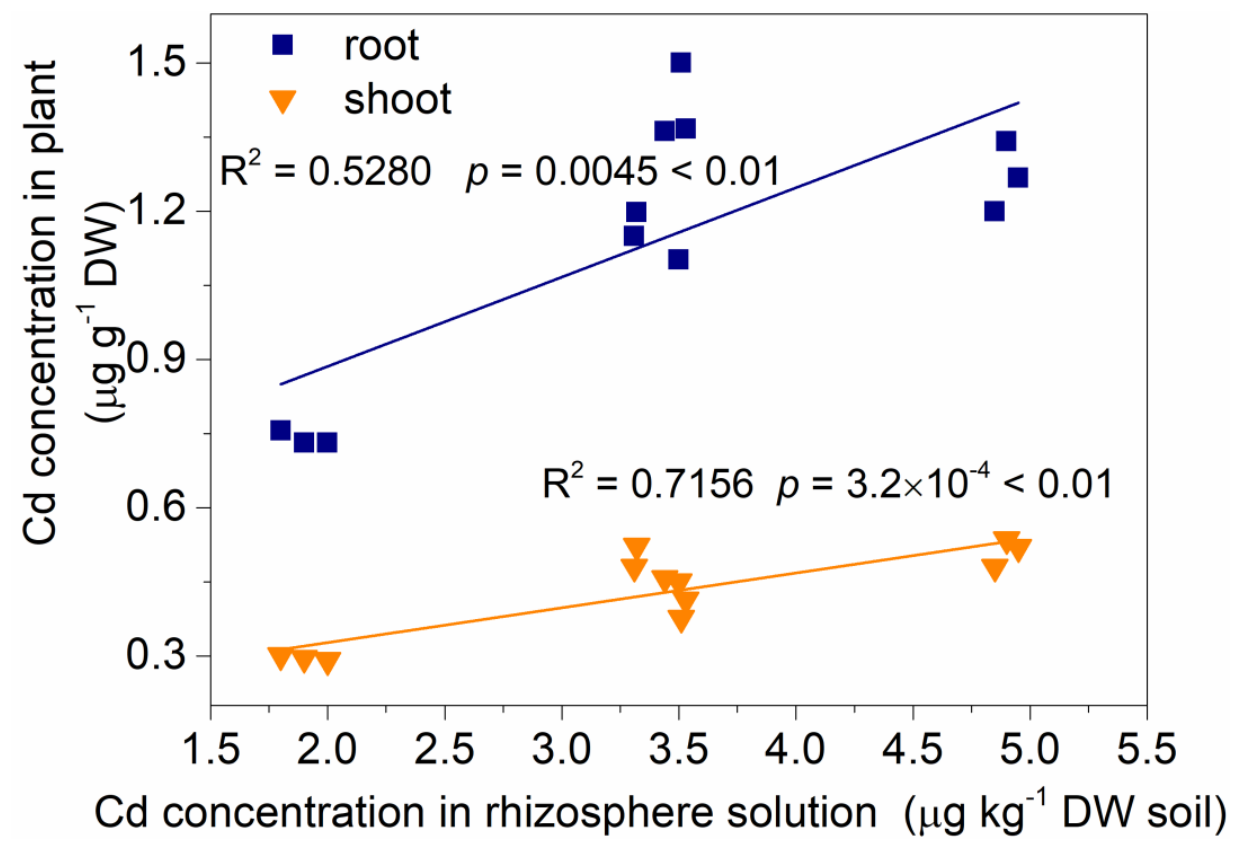

Figure 3. Correlation of $\mathrm{Cd}_{\text {rhizo }}$ with $\mathrm{Cd}_{\text {root}}$, and $\mathrm{Cd}_{\text {shoot }}$ in amaranth after exogenous glycinebetaine treatment.

\subsection{Changes in $\mathrm{Ca}, \mathrm{Mg}$ and $\mathrm{Fe}$ Contents in the Leaves and their Relationship with $\mathrm{Cd}$ Uptake by Edible Amaranth}

Figure 4a-c show that after exogenous glycinebetaine treatment, the $\mathrm{Ca}, \mathrm{Mg}$ and Fe contents in the leaves were significantly higher $(p<0.05)$ than those in the control, whereas $\mathrm{Cd}_{\text {leaf }}$, which denoted the $\mathrm{Cd}$ concentration in the leaves, was positively correlated with the $\mathrm{Ca}, \mathrm{Mg}$ and $\mathrm{Fe}$ contents $(p<0.01)$ (Figure $4 \mathrm{~d}$ ). Cd is a non-essential element for plant growth that typically enters plants through $\mathrm{Ca}$ and $\mathrm{Mg}$ channels on the plasma membrane or zinc and ferric transporters [30,31,36,37]. For example, $\mathrm{Cd}$ can enter rice through Fe transporters [38] and the non-hyperaccumulating ecotype of Sedum alfredii through Ca channels [39]. These results implied that glycinebetaine increased the $\mathrm{Ca}, \mathrm{Mg}$, and $\mathrm{Fe}$ contents in the leaves; provided more shared absorption and translocation channels, such as $\mathrm{Ca}$ and $\mathrm{Fe}$, for $\mathrm{Cd}$; and enhanced the $\mathrm{Cd}$ uptake and accumulation in amaranth leaves. 


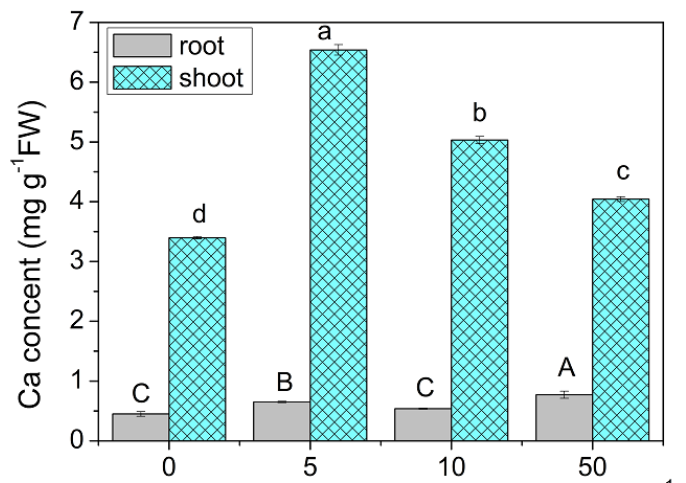

Exogenous glycinebetaine treatment $\left(\mathrm{mmol} \mathrm{L}^{-1}\right)$

(a)

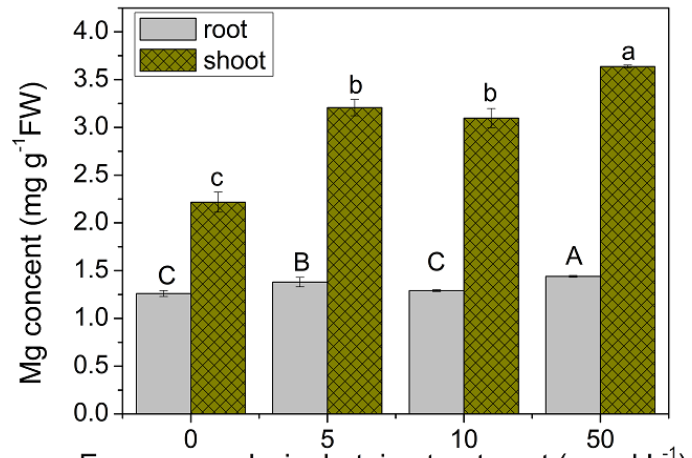

Exogenous glycinebetaine treatment $\left(\mathrm{mmol} \mathrm{L}^{-1}\right)$ (b)

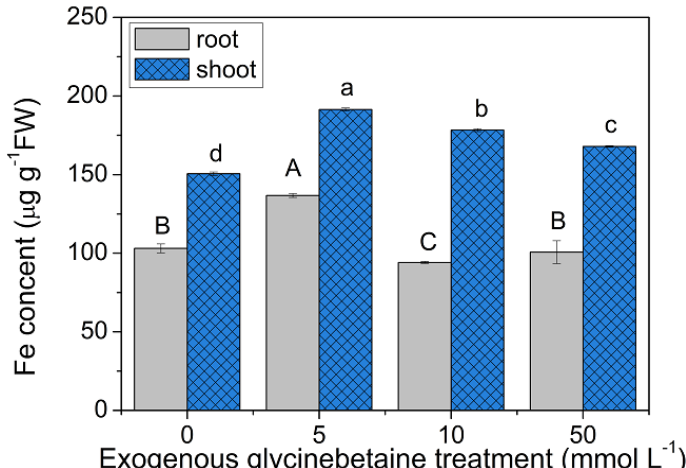

(c)

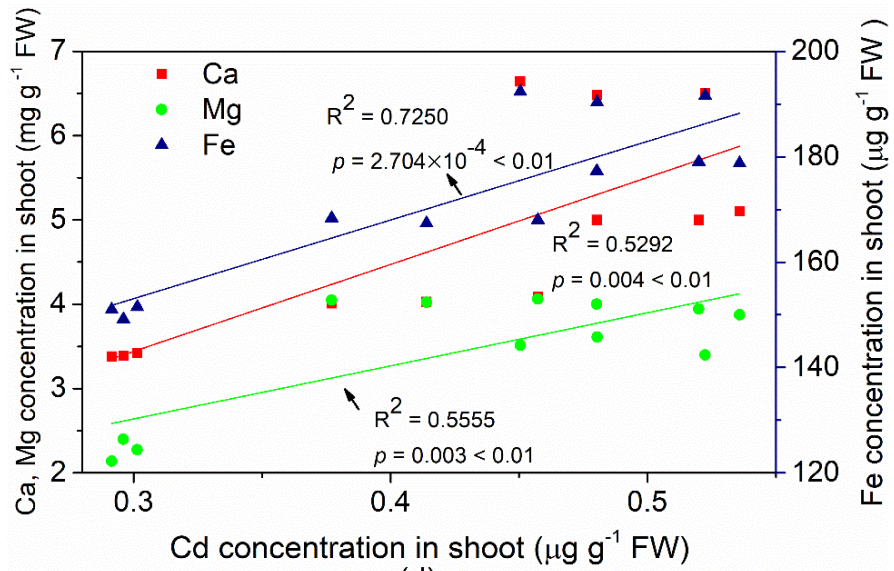

(d)

Figure 4. Ca (a), $\mathrm{Mg}(\mathbf{b})$, and Fe contents (c) (fresh weight) in the plants of control and exogenous glycinebetaine treatments and their relationships with $\mathrm{Cd}$ content $(\mathbf{d})$ in the leaves after exogenous glycinebetaine treatment. Different lowercase letters indicate significant difference between treatments in leaf (ANOVA Duncan test, $p<0.05$ ). Different capital letters indicate significant difference between treatments in root (ANOVA Duncan test, $p<0.05)$. The number of each group sample was five $(n=5)$. 


\subsection{Changes in the Pectin and Chlorophyll Contents and Their Relationship with the Cd Uptake and Accumulation in Amaranth Leaves}

Figure 5 shows the pectin and chlorophyll contents in the leaves after exogenous glycinebetaine treatment. As shown in Figure 5, exogenous glycinebetaine treatment increased the chlorophyll content in the leaves. When the glycinebetaine concentration was $5 \mathrm{mM}$, the chlorophyll content increased by $8.4 \%$ relative to that in the control. This finding was consistent with the results reported in the literature, which stated that exogenous glycinebetaine treatment increases the chlorophyll content in tomatoes [40,41] and maize [6]. Glycinebetaine can improve the activity of various enzymes and photosynthetic pigments under high-temperature stress and can promote chlorophyll synthesis [9]. The leaf chlorophyll content was significantly positively correlated $(p<0.05)$ with the $\mathrm{Mg}$ and $\mathrm{Fe}$ contents (Table 3). Mg and Fe are important elements for chlorophyll enzymes. An increase in chlorophyll content increases the contents of chlorophyllase, $\mathrm{Mg}$, and Fe. Therefore, we speculate that as glycinebetaine enhances photosynthesis and leaf chlorophyll synthesis, the demand for $\mathrm{Mg}$ and $\mathrm{Fe}$ in the leaves increases, thereby edible amaranth potentially induce the high expression of $\mathrm{Mg}$ and Fe absorption channel proteins. $\mathrm{Mg}$ and Fe share these channels with $\mathrm{Cd}$, thereby promoting $\mathrm{Cd}$ accumulation in the leaves (Figure $4 \mathrm{~d}$ ).

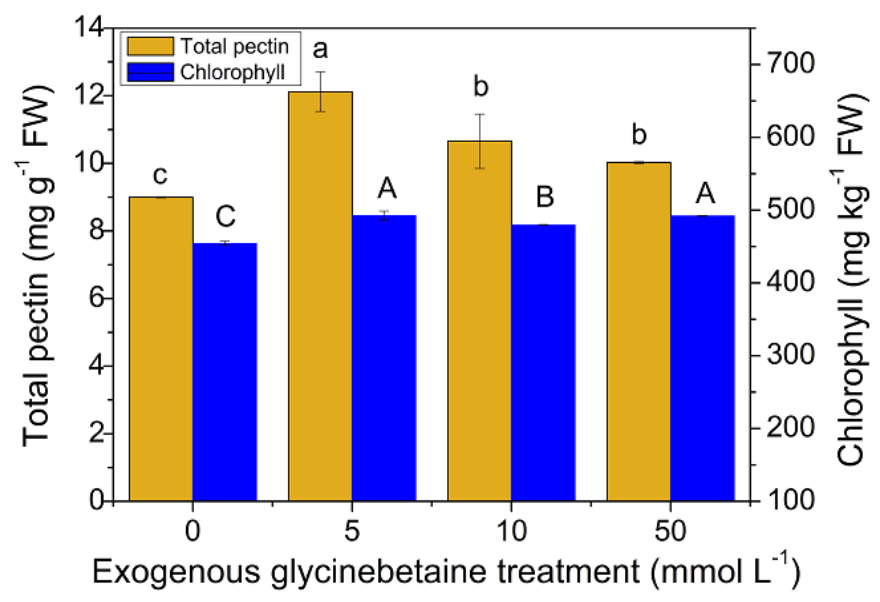

Figure 5. Pectin and chlorophyll contents (fresh weight) in leaves after exogenous glycinebetaine treatment. Different lowercase letters indicate significant difference between treatments for total pectin (ANOVA Duncan test, $p<0.05$ ). Different capital letters indicate significant difference between treatments for chlorophyll (ANOVA Duncan test, $p<0.05$ ). The number of each group sample was five $(n=5)$.

Table 3. Correlations among pectin, chlorophyll, $\mathrm{Ca}, \mathrm{Mg}$, and Fe contents in the leaves after exogenous glycinebetaine treatment.

\begin{tabular}{cccccc}
\hline & Ca & Mg & Fe & Pectin & Chlorophyll \\
\hline $\mathrm{Ca}$ & 1 & & & & \\
$\mathrm{Mg}$ & 0.095 & 1 & & & \\
$\mathrm{Fe}$ & $0.924^{*}$ & 0.344 & 1 & & \\
Total pectin & $0.856^{*}$ & 0.171 & 0.448 & 1 & \\
Chlorophyll & 0.370 & $0.679 *$ & $0.589 *$ & 0.479 & 1 \\
\hline
\end{tabular}

Asterisks $\left.{ }^{*}\right)$ denote statistically significant correlations between the two factors $(p<0.05)$. The number of each group sample was five $(n=5)$.

Figure 5 also shows that exogenous glycinebetaine treatment significantly increased the pectin content in the leaves $(p<0.05)$. Pectin is a matrix polysaccharide in the cell wall, and it can selectively bind heavy metals to promote their accumulation in the leaves. Osmoregulatory substances can 
enhance the ability of pectin to bind heavy metals by altering polysaccharide metabolism and pectin composition [42,43]. An increase in the content of low methyl-esterified pectin in plant cell walls can increase the uptake and accumulation of heavy metals in plants [44]. Therefore, we speculate that exogenous glycinebetaine treatment increases the pectin content in the leaves, which further increases the $\mathrm{Cd}$ adsorption on the cell walls of leaves.

Table 3 shows that a significant positive correlation $(p<0.05)$ existed between the pectin and Ca contents in the leaves. Ca is the main body component of plant cell walls, and pectin calcium is formed in the intercellular layer of the cell walls. Therefore, increased pectin content increases the Ca content, which may induce high expression of Ca absorption channel proteins in the leaf cell membrane. Some of these channels have a low affinity and can also absorb $\mathrm{Cd}$, promoting the $\mathrm{Cd}$ uptake in the leaves [30].

\section{Conclusions}

Exogenous glycinebetaine treatment on leaves in the hot season alleviated high-temperature stress but promoted the soil $\mathrm{Cd}$ uptake and accumulation by edible amaranth. Exogenous glycinebetaine treatment significantly increased the contents of soluble sugar, DOC, and LMWOAs in the rhizosphere soil solution $(p<0.05)$ and enhanced the soil Cd mobilization. In addition, exogenous glycinebetaine treatment significantly increased the chlorophyll and pectin contents in the leaves, which further increased the demand for $\mathrm{Fe}, \mathrm{Mg}$, and $\mathrm{Ca}$. More $\mathrm{Cd}$ was absorbed and accumulated in the leaves through channels of these elements. These results indicated that exogenous glycinebetaine treatment in the subtropical hot season would increase the health risks of crops grown in Cd-contaminated soils.

Author Contributions: Q.-S.L. conceived and designed the study. Y.-K.L. and Z.-M.X. performed the survey. W.-Q.Y. and P.Y. analyzed the data and wrote the paper. L.-L.W. and B.-Y.H. managed and coordinated the research activity planning and execution. C.Z. and H.-J.Y. performed statistical analysis.

Funding: This research was funded by the [National Natural Science Foundation of China] grant number [41371321] and the [Department of Science and Technology of Guangdong Province, China] grant number [2017A010105005].

Conflicts of Interest: The authors declare no conflict of interest.

\section{References}

1. Singh, M.; Kumar, J.; Singh, S.; Singh, V.P.; Prasad, S.M. Roles of osmoprotectants in improving salinity and drought tolerance in plants: A review. Rev. Environ. Sci. Bio/Technol. 2015, 14, 407-426. [CrossRef]

2. Nusrat, N.; Shahbaz, M.; Perveen, S. Modulation in growth, photosynthetic efficiency, activity of antioxidants and mineral ions by foliar application of glycinebetaine on pea (Pisum sativum L.) under salt stress. Acta Physiol. Plant. 2014, 36, 2985-2998. [CrossRef]

3. Wei, D.; Zhang, W.; Wang, C.; Meng, Q.; Li, G.; Chen, T.H.H.; Yang, X. Genetic engineering of the biosynthesis of glycinebetaine leads to alleviate salt-induced potassium efflux and enhances salt tolerance in tomato plants. Plant Sci. 2017, 257, 74-83. [CrossRef] [PubMed]

4. Salama, K.H.A.; Mansour, M.M.; Al-Malawi, H.A. Glycinebetaine priming improves salt tolerance of wheat. Biologia 2015, 70, 1334-1339. [CrossRef]

5. Korkmaz, A.; Şirikçi, R.; Kocaçınar, F.; Değer, Ö.; Demirkırıan, A.R. Alleviation of salt-induced adverse effects in pepper seedlings by seed application of glycinebetaine. Sci. Hortic. 2012, 148, 197-205. [CrossRef]

6. Anjum, S.A.; Farooq, M.; Wang, L.C.; Xue, L.L.; Wang, S.G.; Wang, L.; Zhang, S.; Chen, M. Gas exchange and chlorophyll synthesis of maize cultivars are enhanced by exogenously-applied glycinebetaine under drought conditions. Plant Soil Environ. 2011, 57, 326-331. [CrossRef]

7. Raza, M.A.S.; Saleem, M.F.; Jamil, M.; Khan, I.H. Impact of foliar applied glycinebetaine on growth and physiology of wheat (Triticum aestivum L.) under drought conditions. Pak. J. Agric. Sci. 2014, 51, 327-334.

8. Park, E.-J.; Jeknic, Z.; Chen, T.H.H. Exogenous application of glycinebetaine increases chilling tolerance in tomato plants. Plant Cell Physiol. 2006, 47, 706-714. [CrossRef] [PubMed] 
9. Kanechi, M.; Hikosaka, Y.; Uno, Y. Application of sugarbeet pure and crude extracts containing glycinebetaine affects root growth, yield, and photosynthesis of tomato grown during summer. Sci. Hortic. 2013, 152, 9-15. [CrossRef]

10. Li, S.; Li, F.; Wang, J.; Zhang, W.; Meng, Q.; Chen, T.H.H.; Murata, N.; Yang, X. Glycinebetaine enhances the tolerance of tomato plants to high temperature during germination of seeds and growth of seedlings. Plant Cell Environ. 2011, 34, 1931-1943. [CrossRef] [PubMed]

11. Mäkelä, P.; Jokinen, K.; Kontturi, M.; Peltonen-Sainio, P.; Pehu, E.; Somersalo, S. Foliar application of glycinebetaine-A novel product from sugar beet-As an approach to increase tomato yield. Ind. Crop. Prod. 1998, 7, 139-148. [CrossRef]

12. Mäkelä, P.; Kontturi, M.; Pehu, E.; Somersalo, S. Photosynthetic response of drought- and salt-stressed tomato and turnip rape plants to foliar-applied glycinebetaine. Physiol. Plant. 1999, 105, 45-50. [CrossRef]

13. Alia; Kondo, Y.; Sakamoto, A.; Nonaka, H.; Hayashi, H.; Saradhi, P.P.; Chen, T.H.H.; Murata, N. Enhanced tolerance to light stress of transgenic arabidopsis plants that express the coda gene for a bacterial choline oxidase. Plant Mol. Biol. 1999, 40, 279-288. [CrossRef] [PubMed]

14. Wang, G.-P.; Tian, F.-X.; Zhang, M.; Wang, W. The overaccumulation of glycinebetaine alleviated damages to psii of wheat flag leaves under drought and high temperature stress combination. Acta Physiol. Plant. 2014, 36, 2743-2753. [CrossRef]

15. Alia; Hayashi, H.; Chen, T.H.H.; Murata, N. Transformation with a gene for choline oxidase enhances the cold tolerance of arabidopsis during germination and early growth. Plant Cell Environ. 1998, 21, 232-239. [CrossRef]

16. Wang, G.P.; Zhang, X.Y.; Li, F.; Luo, Y.; Wang, W. Overaccumulation of glycine betaine enhances tolerance to drought and heat stress in wheat leaves in the protection of photosynthesis. Photosynthetica 2010, 48, 117-126. [CrossRef]

17. Lin, X.; Mou, R.; Cao, Z.; Xu, P.; Wu, X.; Zhu, Z.; Chen, M. Characterization of cadmium-resistant bacteria and their potential for reducing accumulation of cadmium in rice grains. Sci. Total Environ. 2016, 569-570, 97-104. [CrossRef] [PubMed]

18. Bian, R.; Joseph, S.; Cui, L.; Pan, G.; Li, L.; Liu, X.; Zhang, A.; Rutlidge, H.; Wong, S.; Chia, C.; et al. A three-year experiment confirms continuous immobilization of cadmium and lead in contaminated paddy field with biochar amendment. J. Hazard. Mater. 2014, 272, 121-128. [CrossRef] [PubMed]

19. Islam, M.M.; Hoque, M.A.; Okuma, E.; Banu, M.N.A.; Shimoishi, Y.; Nakamura, Y.; Murata, Y. Exogenous proline and glycinebetaine increase antioxidant enzyme activities and confer tolerance to cadmium stress in cultured tobacco cells. J. Plant Physiol. 2009, 166, 1587-1597. [CrossRef] [PubMed]

20. Ali, Q.; Ashraf, M. Exogenously applied glycinebetaine enhances seed and seed oil quality of maize (Zea mays L.) under water deficit conditions. Environ. Exp. Bot. 2011, 71, 249-259. [CrossRef]

21. Hossain, M.A.; Hasanuzzaman, M.; Fujita, M. Up-regulation of antioxidant and glyoxalase systems by exogenous glycinebetaine and proline in mung bean confer tolerance to cadmium stress. Physiol. Mol. Biol. Plants 2010, 16, 259-272. [CrossRef] [PubMed]

22. Cao, F.; Liu, L.; Ibrahim, W.; Cai, Y.; Wu, F. Alleviating effects of exogenous glutathione, glycinebetaine, brassinosteroids and salicylic acid on cadmium toxicity in rice seedlings (Oryza sativa). Agrotechnology 2013, 2, 107. [CrossRef]

23. Farooq, M.A.; Ali, S.; Hameed, A.; Bharwana, S.A.; Rizwan, M.; Ishaque, W.; Farid, M.; Mahmood, K.; Iqbal, Z. Cadmium stress in cotton seedlings: Physiological, photosynthesis and oxidative damages alleviated by glycinebetaine. S. Afr. J. Bot. 2016, 104, 61-68. [CrossRef]

24. Zhang, H.; Chen, J.; Zhu, L.; Yang, G.; Li, D. Transfer of Cadmium from Soil to Vegetable in the Pearl River Delta area, South China. PLoS ONE 2014, 9, e108572. [CrossRef] [PubMed]

25. Li, Q.; Chen, Y.; Fu, H.; Cui, Z.; Shi, L.; Wang, L.; Liu, Z. Health risk of heavy metals in food crops grown on reclaimed tidal flat soil in the Pearl River Estuary, China. J. Hazard. Mater. 2012, 227-228, 148-154. [CrossRef] [PubMed]

26. He, Y.; Liu, Y.; Fang, B.; Li, C.; Yang, J.; Teng, Z.; He, X.; Zhang, Y. Effect of temperature on cadmium content of brown rice in different cultrivars. China Rice (Chin.) 2016, 22, 31-35.

27. Irigoyen, J.J.; Einerich, D.W.; Sánchez-Díaz, M. Water stress induced changes in concentrations of proline and total soluble sugars in nodulated alfalfa (Medicago sativd) plants. Physiol. Plant. 1992, 84, 55-60. [CrossRef] 
28. Xu, W.; Wang, C.-W.; Wang, W.-G.; Zhang, J.-F. Quick determination of pectin in pectin extract from premna microphylla. Food Drug (Chin.) 2006, 8, 53-54.

29. Li, Q.; Cai, S.; Mo, C.; Chu, B.; Peng, L.; Yang, F. Toxic effects of heavy metals and their accumulation in vegetables grown in a saline soil. Ecotoxicol. Environ. Saf. 2010, 73, 84-88. [CrossRef] [PubMed]

30. He, B.-Y.; Yu, D.-P.; Chen, Y.; Shi, J.-L.; Xia, Y.; Li, Q.-S.; Wang, L.-L.; Ling, L.; Zeng, E.Y. Use of low-calcium cultivars to reduce cadmium uptake and accumulation in edible amaranth (Amaranthus mangostanus L.). Chemosphere 2017, 171, 588-594. [CrossRef] [PubMed]

31. He, B.; Ling, L.; Zhang, L.; Li, M.; Li, Q.; Mei, X.; Li, H.; Tan, L. Cultivar-specific differences in heavy metal (Cd, $\mathrm{Cr}, \mathrm{Cu}, \mathrm{Pb}$, and $\mathrm{Zn}$ ) concentrations in water spinach (Ipomoea aquatic 'Forsk') grown on metal-contaminated soil. Plant Soil 2015, 386, 251-262. [CrossRef]

32. Gao, Y.; Li, C.; Lou, K. Effect of spraying glycine betaine on physiological responses of processing tomato under drought stress. J. Plant Nutr. Fertil. (Chin.) 2012, 18, 426-432.

33. Dessureault-Rompré, J.; Luster, J.; Schulin, R.; Tercier-Waeber, M.-L.; Nowack, B. Decrease of labile Zn and $\mathrm{Cd}$ in the rhizosphere of hyperaccumulating Thlaspi caerulescens with time. Environ. Pollut. 2010, 158, 1955-1962. [CrossRef] [PubMed]

34. Yanai, J.; Zhao, F.-J.; McGrath, S.P.; Kosaki, T. Effect of soil characteristics on Cd uptake by the hyperaccumulator Thlaspi caerulescens. Environ. Pollut. 2006, 139, 167-175. [CrossRef] [PubMed]

35. Xu, Z.-M.; Li, Q.-S.; Yang, P.; Ye, H.-J.; Chen, Z.-S.; Guo, S.-H.; Wang, L.-L.; He, B.-Y.; Zeng, E.Y. Impact of osmoregulation on the differences in cd accumulation between two contrasting edible amaranth cultivars grown on cd-polluted saline soils. Environ. Pollut. 2017, 224, 89-97. [CrossRef] [PubMed]

36. Vaculík, M.; Konlechner, C.; Langer, I.; Adlassnig, W.; Puschenreiter, M.; Lux, A.; Hauser, M.-T. Root anatomy and element distribution vary between two Salix caprea isolates with different $\mathrm{Cd}$ accumulation capacities. Environ. Pollut. 2012, 163, 117-126. [CrossRef] [PubMed]

37. Carrier, P.; Baryla, A.; Havaux, M. Cadmium distribution and microlocalization in oilseed rape (Brassica napus) after long-term growth on cadmium-contaminated soil. Planta 2003, 216, 939-950. [PubMed]

38. Nakanishi, H.; Ogawa, I.; Ishimaru, Y.; Mori, S.; Nishizawa, N.K. Iron deficiency enhances cadmium uptake and translocation mediated by the $\mathrm{Fe}^{2+}$ transporters OsIRT1 and OsIRT2 in rice. Soil Sci. Plant Nutr. 2006, 52, 464-469. [CrossRef]

39. Lu, L.; Tian, S.; Zhang, M.; Zhang, J.; Yang, X.; Jiang, H. The role of Ca pathway in Cd uptake and translocation by the hyperaccumulator Sedum alfredii. J. Hazard. Mater. 2010, 183, 22-28. [CrossRef] [PubMed]

40. Goel, D.; Singh, A.K.; Yadav, V.; Babbar, S.B.; Murata, N.; Bansal, K.C. Transformation of tomato with a bacterial $\operatorname{codA}$ gene enhances tolerance to salt and water stresses. J. Plant Physiol. 2011, 168, 1286-1294. [CrossRef] [PubMed]

41. Mäkelä, P.; Kärkkäinen, J.; Somersalo, S. Effect of glycinebetaine on chloroplast ultrastructure, chlorophyll and protein content, and RuBPCO activities in tomato grown under drought or salinity. Biol. Plant. 2000, 43, 471-475. [CrossRef]

42. Wu, Q.-S.; Zou, Y.-N.; He, X.-H. Contributions of arbuscular mycorrhizal fungi to growth, photosynthesis, root morphology and ionic balance of citrus seedlings under salt stress. Acta Physiol. Plant. 2010, 32, 297-304. [CrossRef]

43. Brunner, I.; Luster, J.; Günthardt-Goerg, M.S.; Frey, B. Heavy metal accumulation and phytostabilisation potential of tree fine roots in a contaminated soil. Environ. Pollut. 2008, 152, 559-568. [CrossRef] [PubMed]

44. Krzesłowska, M. The cell wall in plant cell response to trace metals: Polysaccharide remodeling and its role in defense strategy. Acta Physiol. Plant. 2011, 33, 35-51. [CrossRef]

(C) 2018 by the authors. Licensee MDPI, Basel, Switzerland. This article is an open access article distributed under the terms and conditions of the Creative Commons Attribution (CC BY) license (http://creativecommons.org/licenses/by/4.0/). 